\title{
An in vitro liver model - assessing oxidative stress and genotoxicity following exposure of hepatocytes to a panel of engineered nanomaterials
}

\author{
Ali Kermanizadeh ${ }^{1 *}$, Birgit K Gaiser ${ }^{1}$, Gary R Hutchison ${ }^{2}$ and Vicki Stone ${ }^{1}$
}

\begin{abstract}
Background: Following exposure via inhalation, intratracheal instillation or ingestion some nanomaterials (NM) have been shown to translocate to the liver. Since oxidative stress has been implicated as a possible mechanism for $\mathrm{NM}$ toxicity this study aimed to investigate the effects of various materials (five titanium dioxide $\left(\mathrm{TiO}_{2}\right.$ ), two zinc oxide ( $\mathrm{ZnO}$ ), two multi-walled carbon nanotubes (MWCNT) and one silver (Ag) NM) on oxidative responses of C3A cell line as a model for potential detrimental properties of nanomaterials on the liver.

Results: We noted a dose dependant decrease in the cellular glutathione content following exposure of the C3A cells to Ag, the $\mathrm{ZnO}$ and the MWCNTs. Intracellular ROS levels were also measured and shown to increase significantly following exposure of the C3A to the low toxicity NMs $\left(\mathrm{MWCNT}\right.$ and $\left.\mathrm{TiO}_{2}\right)$. The antioxidant Trolox in part prevented the detrimental effect of NMs on cell viability, and decreased the NM induced IL8 production after exposure to all but the Ag particulate. Following $4 \mathrm{hr}$ exposure of the C3A cells to sub-lethal levels of the NMs, the largest amount of DNA damage was induced by two of the $\mathrm{TiO}_{2}$ samples $(7 \mathrm{~nm}$ and the positively charged $10 \mathrm{~nm}$ particles).

Conclusions: All ten NMs exhibited effects on the hepatocyte cell line that were at least in part ROS/oxidative stress mediated. These effects included mild genotoxicity and IL8 production for all NM except the Ag possibly due to its highly cytotoxic nature.
\end{abstract}

Keywords: Liver, Nanomaterials, Oxidative stress, Antioxidant, Genotoxicity

\section{Background}

As the field of nanotechnology develops, there are now over 1300 consumer products on the market with a claim to contain elements of nanotechnology [1]. The potential for public and occupational exposure is therefore likely to increase, and so there is an urgent necessity to consider the possibility of any detrimental health consequences with this increased exposure to nanomaterials. This is achieved in the form of a critical risk assessment conducted as part of a large consortium (FP7 project ENPRA - Risk Assessment of Engineered Nanoparticle).

\footnotetext{
*Correspondence: ak435@hw.ac.uk

${ }^{1}$ Heriot-Watt University, School of Life Sciences, Nanosafety Research Group, Edinburgh EH14 4AS, UK

Full list of author information is available at the end of the article
}

The risk is assessed based upon the level of exposure to the manufactured NM, toxicity of the particle in question, route of exposure and the persistence in the organism of the particular material. Hence it is crucial to identify the hazards associated with NM exposure both in vitro and in vivo, consequently assembling a knowledge base of the human health effects associated with $\mathrm{NM}$ exposure [2]. Engineered nanomaterials are manufactured from a diverse group of substances each with an array of unique physicochemical characteristics, hence a varied range of materials need to be evaluated for a comprehensive toxicity profile allowing for a structure activity relationship to be generated. It is likely that NMs will differ in the levels of toxicity induced and the mechanism by which they exert these adverse effects.




Therefore we investigated a panel of ten widely used nanomaterials (five different $\mathrm{TiO}_{2}$, two MWCNTs, two $\mathrm{ZnO}$ and one $\mathrm{Ag}$ ).

The lungs and the gastrointestinal tract are in constant contact with the external environment so it is not surprising to find these systems being primary exposure sites for NMs [3,4]. It is believed that NMs administered via the ingestion, inhalation or intravenous injection might eventually reach secondary tissues, one of which is the liver $[5,6]$.

The liver is the metabolic centre of the body [6]. It has a crucial role in metabolic homeostasis, as it is responsible for the storage, synthesis, metabolism and redistribution of carbohydrates, fats and vitamins. It also produces large numbers of serum proteins and an array of enzymes and cytokines [7]. The liver receives and accumulates materials at much higher volumes compared to other organs and alongside the kidneys might be responsible for the clearance of NMs from the blood $[6,8,9]$. Previous studies have shown that the uptake and translocation of $\mathrm{TiO}_{2} \mathrm{NMs}$ following intratracheal instillation has resulted in accumulation of nanomaterials within the liver [8-10].

There is an abundant body of evidence suggesting the involvement of oxidative stress in the pathogenesis of various disorders and diseases. Reactive oxygen species (ROS) and other free radicals are critical intermediates in the normal physiology and pathophysiology of the liver [5]. Oxygen species are important in the creation of oxidative stimuli required for normal physiologic homeostasis of hepatocytes, as well as playing a role in gene expression [5]. Since ROS are ubiquitous in the normal physiology of so many processes, it is not surprising that when excess ROS are produced, some normal functions of healthy cells are affected.

To combat excess ROS, cells utilise antioxidants. If the equilibrium between ROS generation and the antioxidant defence within a cell is disrupted it may result in oxidative stress [11]. Common antioxidants in hepatocytes include glutathione (GSH), glutathione peroxidase, superoxide dismutase (SOD), hemeoxygenase (HO) and peroxidases [12]. Glutathione is a ubiquitous tri-peptide which primarily functions to react with hydrogen peroxide utilising glutathione peroxidise to create glutathione disulfide (GSSG). GSH also scavenges other ROS molecules and prevents oxidation of protein sulfhydryl groups [5].

The effects of oxidative stress are usually dependent upon the size of these changes, with a cell being able to overcome small perturbations and regain its original state. However, long lasting or severe oxidative stress can cause cell damage and death. Even moderate oxidative stress can trigger apoptosis, while more intense stress may cause necrosis [13]. Mild ROS/oxidative stress can activate cells via redox sensitive transcription factors (i.e. NFk $\beta$ ) leading to elevated gene expression of pro-inflammatory mediators [14], while severe ROS insult can lead to genotoxicity $[15,16]$.

The nanomaterials in this study were chosen due to their varied physicochemical characteristics, their relevance to the OECD (Organisation for Economic Cooperation and Development) sponsored programme and their frequent use in various industries. In this study intracellular levels of glutathione were measured in human hepatoblastoma $\mathrm{C} 3 \mathrm{~A}$ cell line as well as intracellular ROS using the $2^{\prime} 7^{\prime}$ - dichlorofluorescin diacetate (DCFH-DA) assay. Antioxidants were used to investigate the role of ROS in the responses observed. Furthermore, the short term genotoxic properties of the panel of materials was investigated utilising the widely acknowledged comet assay.

\section{Methods}

\section{Nanomaterials}

Nanomaterials were purchased as stated: NM 101 (Hombikat UV100; rutile with minor anatase; $7 \mathrm{~nm}$ ), NM 110 (BASF Z-Cote; zinkite, uncoated, 100 nm), NM 111 (BASF Z-Cote; zinkite coated with triethoxycaprylylsilane, $130 \mathrm{~nm}$ ), NM 300 (RAS GmbH; Ag capped with polyoxylaurat Tween $20-<20 \mathrm{~nm}$ ), NM 400 (Nanocyl; entangled MWCNT, diameter $30 \mathrm{~nm}$, length $5 \mu \mathrm{m}$ ), NM 402 (Arkema Graphistrength C100; entangled MWCNT, diameter $30 \mathrm{~nm}$, length $20 \mu \mathrm{m}$ ). The above mentioned nanomaterials were sub-sampled under Good Laboratory Practice conditions and preserved under argon in the dark until use. These NMs were received from the European Commission Joint Research Centre (Ispra, Italy). The NRCWE samples were procured by the National Research Centre for the Working Environment. Sub-sampling was completed into $20 \mathrm{ml}$ Scint-Burk glass pp-lock with Alu-Foil (WHEA986581; Wheaton Industries Inc.) after pooling and mixing of the material. NRCWE 001, $\mathrm{TiO}_{2}$ rutile $10 \mathrm{~nm}$ was purchased from NanoAmor (Houston, USA) and also used for production of NRCWE $002\left(\mathrm{TiO}_{2}\right.$ rutile $10 \mathrm{~nm}$ with positive charge) and NRCWE $003\left(\mathrm{TiO}_{2}\right.$ rutile $10 \mathrm{~nm}$ with negative charge) using the procedures described previously [17]. NRCWE 004 $\left(\mathrm{TiO}_{2}\right.$ rutile $\left.94 \mathrm{~nm}\right)$ was purchased from NaBond. A list of the main physical and chemical properties of the panel NMs has been reproduced from previously described work [17] (Table 1).

\section{Cell culture and treatment with nanomaterials}

The human hepatoblastoma C3A cell line was obtained from the American Type Culture Collection (ATCC, USA). The cells were maintained in Minimum Essential Medium Eagle (MEM) with 10\% FCS, $2 \mathrm{mM} \mathrm{L-}$ glutamine, $100 \mathrm{U} / \mathrm{ml}$ Penicillin/Streptomycin, $1 \mathrm{mM}$ 
Table 1 Physicochemical characteristics of engineered nanomaterials investigated - reproduced from Kermanizadeh, et al. [17]

\begin{tabular}{|c|c|c|c|c|c|c|c|c|}
\hline $\begin{array}{l}\text { ENM } \\
\text { code }\end{array}$ & $\begin{array}{l}\text { ENM } \\
\text { type }\end{array}$ & Phase & $\begin{array}{l}\text { XRD } \\
\text { Size[nm] }\end{array}$ & TEM Size & Primary characteristics by TEM analysis & $\begin{array}{l}\text { Surface } \\
\text { area (BET) } \\
{\left[\mathrm{m}^{2} / \mathrm{g}\right]}\end{array}$ & $\begin{array}{l}\text { Known } \\
\text { coating }\end{array}$ & $\begin{array}{l}\text { Size in } \\
\text { MEM } \\
\text { (DLS) } \Psi\end{array}$ \\
\hline NM101 & $\mathrm{TiO}_{2}$ & Anatase $^{\epsilon}$ & 9 & $4-8 / 50-100$ & $\begin{array}{l}\text { Two structures found; type } 1 \text { show } \\
\text { agglomerates in the } 50-1500 \mathrm{~nm} \text { range }\end{array}$ & 322 & none & 185,742 \\
\hline NM110 & $\mathrm{ZnO}$ & Zincite & 70 to $>100$ & $20-250 / 50-350$ & $\begin{array}{l}\text { Mainly } 2 \text { euhedral morphologies: } 1) \text { aspect } \\
\text { ratio close to } 1(20-250 \mathrm{~nm} \text { range and few } \\
\text { particles of approx. } 400 \mathrm{~nm}) 2 \text { ) ratio } 2 \text { to } 7.5 \\
\text { (50-350 nm). Minor amounts of particles } \\
\text { with irregular morphologies observed. }\end{array}$ & 14 & none & 306 \\
\hline NM111 & $\mathrm{ZnO}$ & Zincite & $58-93$ & $20-200 / 10-450$ & $\begin{array}{l}\text { As NM110, but with different size } \\
\text { distributions. 1) particles with aspect ratio } \\
\text { close to } 1(\sim 90 \% \text { in the } 20-200 \mathrm{~nm} \text { range); } \\
\text { 2) particles with aspect ratio } 2 \text { to } 8.5(\sim 90 \% \\
\text { in the } 10-450 \mathrm{~nm} \text { ratio). }\end{array}$ & 18 & $\begin{array}{l}\text { Trie-othoxy- } \\
\text { capry-Isilane } \\
130\end{array}$ & 313 \\
\hline NM300 & $\mathrm{Ag}$ & $\mathrm{Ag}_{\mathrm{m}}$ & $\begin{array}{l}7^{\$} 14^{£} \\
<18 / 15 />100^{\#}\end{array}$ & 8-47 (av.: 17.5) & $\begin{array}{l}\text { Mainly euhedral NP; minor fractions have } \\
\text { either elongated (aspect ratio up to } \sim 5 \text { ) or } \\
\text { sub-spherical morphology. }\end{array}$ & NA & none & $12,28,114$ \\
\hline NM400 & MWCNT & - & - & $\begin{array}{l}\text { D: } 5-35 \mathrm{~L}: \\
700-3000\end{array}$ & $\begin{array}{l}\text { Irregular entangled kinked and mostly } \\
\text { bent MWCNT (10-20 walls). Some CNTs } \\
\text { were capped and some cases multiple } \\
\text { caps were found due to overgrowth. } \\
\text { Fe/Co catalysts (6-9 nm, average } 7.5 \mathrm{~nm} \text { ) } \\
\text { were found inside the tubes. }\end{array}$ & 298 & none & * \\
\hline NM402 & MWCNT & - & - & $\begin{array}{l}\text { D: 6-20L: } \\
700-4000\end{array}$ & $\begin{array}{l}\text { Entangled irregular, mostly bent MWCNT } \\
\text { (6-14 walls). Some tubes were capped } \\
\text { by unknown material. Some nano-onions } \\
\text { ( } 5-10 \mathrm{~nm} \text { ) and amorphous carbon structures } \\
\text { mixed with Fe (5-20 nm). Residual catalyst } \\
\text { was observed. Individual catalyst particles up } \\
\text { to } 150 \mathrm{~nm} \text { were also detected. }\end{array}$ & 225 & none & * \\
\hline NRCWE001 & $\mathrm{TiO}_{2}$ & Rutile $^{\S}$ & 10 & $80-400$ & Irregular euhedral particles detected by TEM. & 99 & none & 203 \\
\hline NRCWE002 & $\mathrm{TiO}_{2}$ & Rutile & 10 & $80-400$ & Irregular euhedral particles detected by TEM. & 84 & $\begin{array}{l}\text { Positive } \\
\text { charged }\end{array}$ & 287 \\
\hline NRCWE003 & $\mathrm{TiO}_{2}$ & Rutile & 10 & $80-400$ & Irregular euhedral particles detected by TEM. & 84 & $\begin{array}{l}\text { Negative } \\
\text { charged }\end{array}$ & 240,1487 \\
\hline NRCWE004 & $\mathrm{TiO}_{2}$ & Rutile & App. 100 & $\begin{array}{l}1-4 / 10-100 / \\
100-200 / \\
1000-2000\end{array}$ & 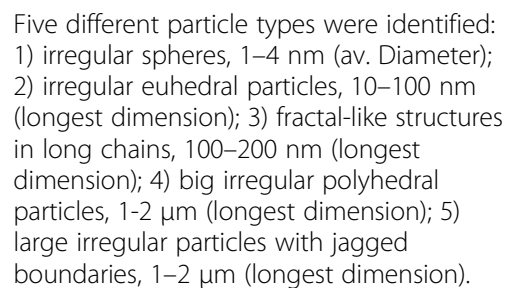 & & & 339 \\
\hline
\end{tabular}

\footnotetext{
$€ 1$ percent rutile found in one of two samples analyzed.

$\$$ wet XRD in capillary tube.

${ }^{£}$ dried samples.

\# sample with deposits.

$\S$ ca. $6 \%$ anatase was observed in one of two samples analyzed.

* Not detectable by DLS due to the very large aspect ratio.

$\psi$ Intensity based size average in biological media after 15 mins.

Abbreviations: D Diamter, DLS Dynamic Light Scattering, ENM Engineered nanomaterial, $L$ Length, $X R D X$ ray diffraction.
}

sodium pyruvate, and $1 \%$ non essential amino acids (here after termed complete medium), at $37^{\circ} \mathrm{C}$ and $5 \%$ $\mathrm{CO}_{2}$. All experiments were conducted using cells between passage 7 and 25 .

The Ag NMs were supplied in de-ionised water with stabilizing agent (7\% ammonium nitrate, $4 \%$ each of Polyoxyethylene Glycerol Trioleate and 4\% Tween 20).
All other NMs were supplied as a dry powder form and dispersed utilising MilliQ de-ionised water with $2 \%$ fecal calf serum (FCS - Sigma B9433), with the exception of the coated $\mathrm{ZnO}$ materials, which were wetted with $0.5 \%$ vol ethanol before the addition of the dispersion media. The nanomaterials were sonicated for 16 mins without pause following the protocol developed for ENPRA [18]. 
Following sonication, all samples were kept on ice until dilution in complete medium.

To examine the toxicity of nanomaterials to C3A cells, NM concentrations between $0.16 \mu \mathrm{g} / \mathrm{cm}^{2}$ and $80 \mu \mathrm{g} / \mathrm{cm}^{2}$ were used (equivalent to $0.5-256 \mu \mathrm{g} / \mathrm{ml}$ ).

\section{Antioxidant pre-treatment}

The C3A cells were seeded in 96 well plates at $10^{4}$ cells per well in $100 \mu \mathrm{l}$ of the complete cell culture medium and incubated for $24 \mathrm{hr}$ at $37^{\circ} \mathrm{C}$ and $5 \% \mathrm{CO}_{2}$. The following day the cells were exposed to the nanomaterials or controls for a further $24 \mathrm{hr}$. In order to investigate the possible intervention of antioxidants on cytotoxicity, ROS or cytokine production from the C3A cells, they were pre-treated with $100 \mu \mathrm{M}$ of Trolox (6-hydroxy2,5,6,7,8-tetramethylchroman-2-carboxylic acid) in complete medium for $1 \mathrm{hr}$. The antioxidant containing medium was removed before the addition of the nanomaterials as described above.

\section{Measurement of total glutathione}

The protocol is adapted from Senft et al. [19]. A $3 \mathrm{ml}$ cell suspension of cultured cells $\left(1 \times 10^{6}\right.$ cells per $\left.\mathrm{ml}\right)$ was added to 6 well plates and incubated overnight at $37^{\circ} \mathrm{C}$ and $5 \% \mathrm{CO}_{2}$. The cells were exposed to the NMs or equivalent control dispersant in complete C3A medium for $24 \mathrm{hr}$ before being scraped into ice cold phosphate buffered saline and centrifuged (700 g for 2 mins). The cell pellet was re-suspended in ice-cold lysis buffer [19], mixed and incubated on ice for 10 mins before being centrifuged at $15000 \mathrm{~g}$ for 5 mins to generate lysates and protein pellets. Glutathione was quantified of the lysate by reaction of sulfhydryl groups with the fluorescent substrate $o$-phthaladehyde (OPT) using a fluorimeter with an excitation wavelength of $350 \mathrm{~nm}$ and emission wavelength of $420 \mathrm{~nm}$.

The protocol was slightly modified to include measurements of total glutathione by reducing oxidised glutathione dimers (GSSG) by addition of $7 \mu \mathrm{l}$ of $10 \mathrm{mM}$ sodium dithionite to all samples and incubating at room temperature for $1 \mathrm{hr}$.

\section{DCFH-DA assay}

C3A cells were seeded on a 96 well plate in complete phenol red free C3A medium $\left(1 \times 10^{4}\right.$ cells per well) and incubated at $37^{\circ} \mathrm{C}, 5 \% \mathrm{CO}_{2}$ for $24 \mathrm{hr}$. The cells were exposed to the NMs or equivalent control (hydrogen peroxide $100 \mu \mathrm{M}$ - positive control) in complete medium for $24 \mathrm{hr}$.

DCFH-DA is air, light and temperature sensitive so great care was taken when preparing the final working concentration of $10 \mu \mathrm{M}$ in $0.9 \% \mathrm{NaCl}$. Following incubation, cells were rinsed and $100 \mu \mathrm{l}$ of DCFH-DA was added before the plates were incubated in the dark at room temperature for $1 \mathrm{hr}$. Cells were rinsed again and
$200 \mu \mathrm{l}$ of $90 \%$ DMSO in PBS was added and incubated on a shaker for 5 mins at room temperature. The plates were wrapped in foil to protect from light before being centrifuged for 2 mins at $250 \mathrm{~g}$. This was followed by the measurement of $150 \mu \mathrm{l}$ of supernatant in black 96 well plates at an excitation wavelength of $485 \mathrm{~nm}$ and emission wavelength of $520 \mathrm{~nm}$.

\section{Detection of DNA strand breaks in C3A cells}

The FPG (formamidopyrimidine [fapy] - DNA glycosylase) modified Comet assay was used to measure DNA strand breaks and specific oxidative DNA damage such as 7, 8-dihydro-8-oxoguanine, 8-oxoadenine, fapyguanine etc., based on the method described by Speit et al. [20]. In this study the tail moment [21] was measured using an automatic image analyser (Comet Assay IV; Perceptive Instruments, UK) connected to a fluorescence microscope. Images were captured using a stingray (F033B/C) black and white video camera.

After a $4 \mathrm{hr}$ NM treatment (or positive control $60 \mu \mathrm{M}$ of $\mathrm{H}_{2} \mathrm{O}_{2}$ ), the C3A cells were rinsed twice with PBS and detached using trypsin before being suspended in $5 \mathrm{ml}$ of culture medium. Cells were centrifuged for 10 mins at $250 \mathrm{~g}, 4^{\circ} \mathrm{C}$ and re-suspended at a concentration of $1.5 \times 10^{6}$ cells $/ \mathrm{ml}$ in complete medium. A $20 \mu \mathrm{l}$ volume of calculated cell suspension was added to $240 \mu \mathrm{l}$ of $0.5 \%$ low melting point agarose. Next, $125 \mu \mathrm{l}$ of the mixture was added to pre-coated slides ( $1.5 \%$ agarose) in triplicate. Following $10 \mathrm{mins}$ of solidification on ice, slides were lyzed overnight at $4^{\circ} \mathrm{C}$ in lysis buffer $(2.5 \mathrm{M}$ $\mathrm{NaCl}, 100 \mathrm{mM}$ EDTA, $10 \mathrm{mM}$ Tris-base, pH 10, containing 10\% DMSO and 1\% TritonX-100). The slides were washed three times for 5 mins with FPG-enzyme buffer ( $40 \mathrm{mM}$ HEPES, $100 \mathrm{mM} \mathrm{KCl,} 0.5 \mathrm{mM}$ EDTA, $0.2 \mathrm{mg} / \mathrm{ml} \mathrm{BSA} \mathrm{-} \mathrm{pH} \mathrm{8),} \mathrm{covered} \mathrm{with} 100 \mu \mathrm{l}$ of either buffer or FPG in buffer (1:30), sealed with a cover slip and incubated for 30 mins at $37^{\circ} \mathrm{C}$. FPG cleaves DNA at locations of oxidation leading to a greater tail for cells exhibiting oxidative DNA damage [22]. All slides were then transferred into a black chilled electrophoresis tank. After alkaline unwinding ( $\mathrm{pH} 13)$ for 20 mins, electrophoresis was performed for 15 mins at $270 \mathrm{~mA}, 24 \mathrm{~V}$. Slides were neutralized three times for 5 mins using a neutralization buffer (0.4 M TrisBase, $\mathrm{pH}$ 7.5). Before analysis, slides were dried on air for 10 mins and stained with GelRed ( 2 in 10000, $40 \mu \mathrm{l}$ per slide). A total of 50 cells were analyzed per slide per experiment.

We also investigated the long term genotoxic ability of Ag NM (NM 300). C3A cells were exposed to the NMs for $24 \mathrm{hr}$ before being allowed to recover for $72 \mathrm{hr}$. The cells were then detached by treating with trypsin before being transferred to a new flask. After $48 \mathrm{hr}$ the cells were treated with the Ag NMs for $24 \mathrm{hr}$, with the whole process being repeated for a period of 8 weeks. 


\section{Statistical analysis}

All data are expressed as mean \pm standard error of the mean. For statistical analysis, the experimental results were compared to their corresponding control values using an ANOVA with Tukey's multiple comparison. All statistical analysis was carried out utilising Minitab 15. A $\mathrm{p}$ value of $<0.05$ was considered to be significant. All experiments were repeated a minimum of three times.

\section{Results}

Impact of the nanomaterials on depletion of GSH in C3A hepatocytes

Analysis of the total glutathione contents of C3A cells revealed a dose dependant decrease compared to the control cells at $24 \mathrm{hr}$ following exposure to five of the ten nanomaterials investigated. These NMs were NM
110 (ZnO uncoated), NM 111 ( $\mathrm{ZnO}$ coated), NM 300 (Ag), NM 400 and NM 402 (2 MWCNTs) (Figure 1b, c, $\mathrm{d}$, e and $\mathrm{f}$ ). The three NMs previously shown to be the most cytotoxic to C3A cells as measured by the WST-1 assay (Ag NM 300, ZnO NM 110 and 111) also proved to induce relatively greater glutathione depletion than the other investigated NMs [17] (figure 1b, c and d - the $\mathrm{LC}_{50}$ is indicated).

\section{Measurement of intracellular ROS}

The $2^{\prime}, 7^{\prime}$-dichlorfluorescein-diacetate assay is based on the principle of DCFH being oxidized to fluorescent dichlorofluorescein (DCF) in the presence of intracellular ROS. We chose six different exposure time points $(2$, $4,6,8,12$ and $24 \mathrm{hr}$ ) and found the $6 \mathrm{hr}$ exposure to be the optimal for the highest levels of intracellular ROS
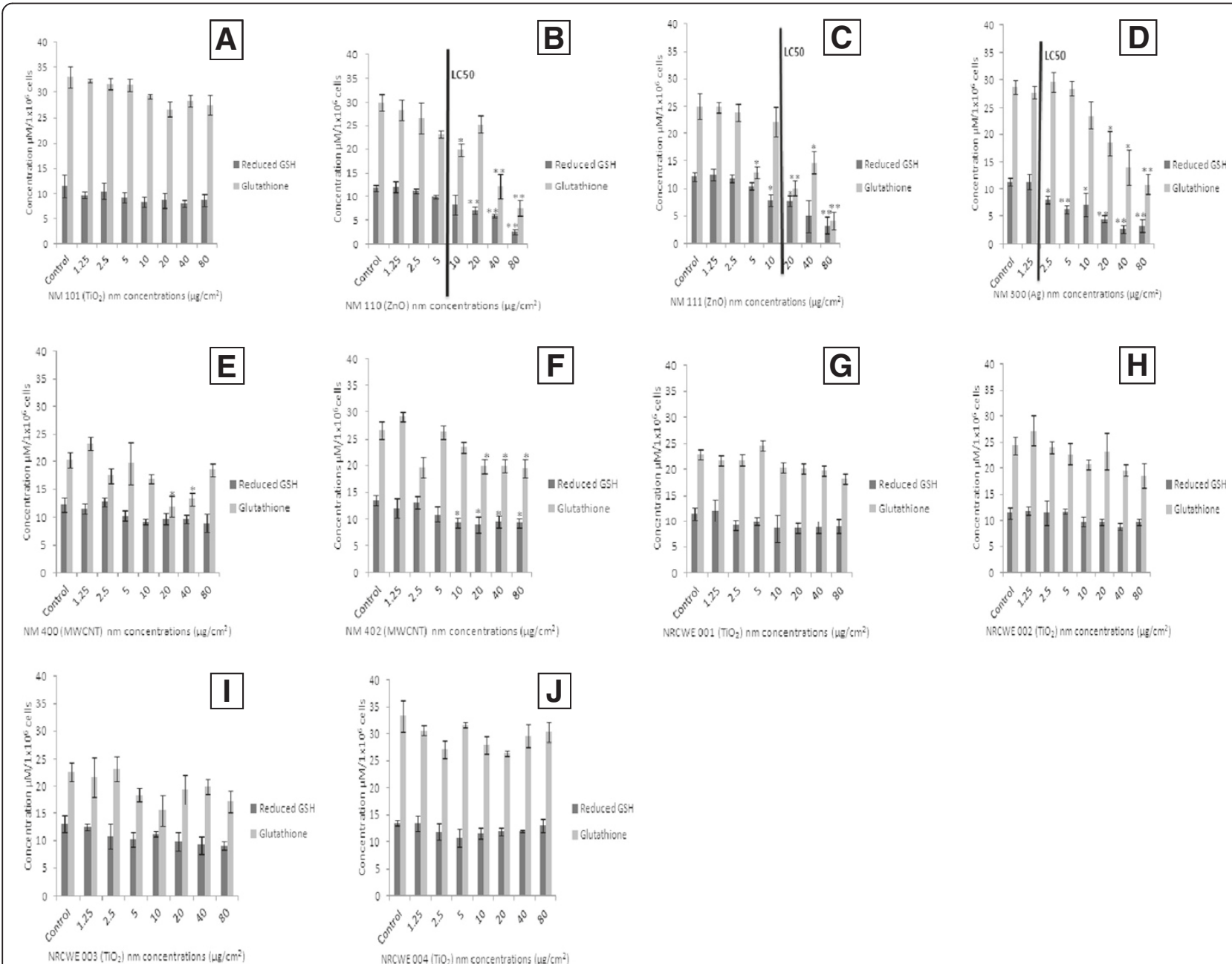

Figure 1 Effects of NM exposure on reduced GSH and total glutathione levels in C3A cells. The cells were exposed to cell medium (control), and increasing concentrations of selected NMs for $24 \mathrm{hr}$. Values represent mean $\pm \operatorname{SEM}(n=3)$, significance indicated by ${ }^{*}=p<0.05$ and ${ }^{* *}=p<0.005$ compared to the control. A) NM 101 B) NM 110 C) NM 111 D) NM 300 E) NM 400 F) NM 402 G) NRCWE 001 H) NRCWE 002 I) NRCWE $003 \mathrm{~J}$ ) NRCWE 004. $L C_{50}$ values are indicated for NMs where this value was measurable. For all other NMs the $L C_{50}$ was not reached following exposure up to $80 \mathrm{\mu g} / \mathrm{cm}^{2}$ after $24 \mathrm{hr}$ of incubation. 


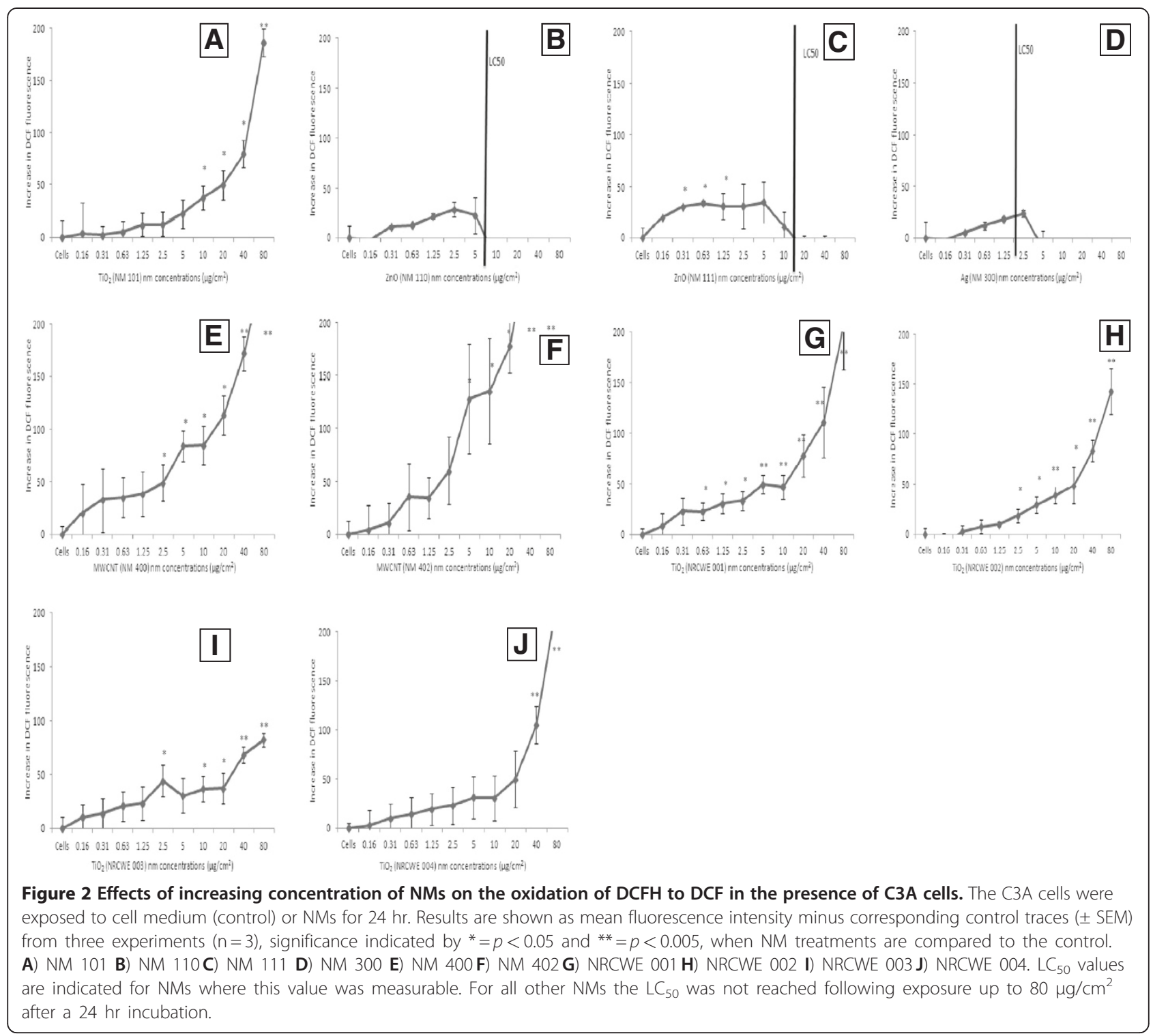

production (data not shown). We noted a dose dependent increase in the levels of DCF fluorescence after exposure to the low toxicity nanomaterials $\left(\mathrm{TiO}_{2}\right.$ and MWCNT NMs - Figure 2a, e, f, g, h and j). Following exposure to the highly toxic $\mathrm{ZnO}$ (NM 110) and $\mathrm{Ag}$ (NM 300) NMs, there was no significant increase in intracellular ROS levels. After exposure of the cells to coated $\mathrm{ZnO}$ (NM 111) there was a small but significant increase of fluorescence up to the $\mathrm{LC}_{50}$ value before a sharp drop at the higher concentrations. The levels of DCF fluorescence after the exposure to the highly toxic NMs were markedly lower than those witnessed after exposure to the low toxicity nanomaterials (Figure 2b, c and d).

In order to investigate whether an antioxidant could prevent the NM-induced ROS production within the hepatocytes - the cells were pre-treated with the vitamin E derivative - Trolox for $1 \mathrm{hr}$ before the addition of the nanomaterials. Trolox prevented the NM induced DCF fluorescence with the inhibition most evident for the two MWCNTs (Figure 3).

The effect of Trolox pre-treatment on cytotoxicity and interleukin 8 (IL8) production from C3A cells

In a previous study we showed that three of the ENPRA panel of nanomaterials were highly cytotoxic (Ag, coated and uncoated $\mathrm{ZnO}$ ). We also witnessed an increase in levels of IL8 production following exposure to the NMs investigated while no change in the levels of IL6, TNF- $\alpha$ or $\mathrm{C}$ reactive protein was witnessed [17]. In this study we aimed to investigate the effects of the pre-treatment with an external antioxidant on cytotoxicity and IL8 


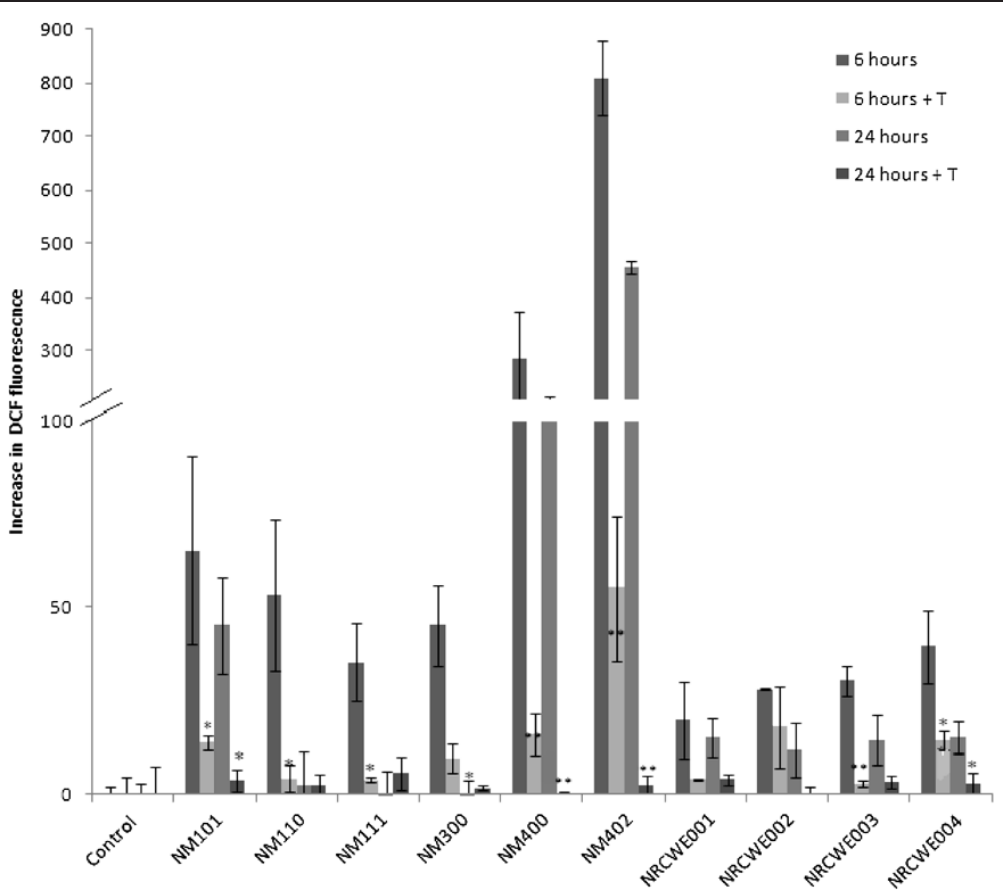

Figure 3 Effect of $20 \mu \mathrm{g} / \mathrm{cm}^{2}$ of ENPRA nanomaterials on the oxidation of DCFH to DCF in C3A cells with and without Trolox pre-treatment. The cells were exposed to cell medium (control) or NMs for 6 or $24 \mathrm{hr}$. Results are exposed as mean fluorescence intensity minus corresponding control traces $\left( \pm\right.$ SEM) from three experiments $(n=3)$, significance indicated by ${ }^{*}=p<0.05$ and ${ }^{* *}=p<0.005$, when decrease in fluorescence is compared to cells not treated with Trolox (T) before exposure to the NMs.

production from the cells. The C3A hepatocytess were pre-treated with Trolox for $1 \mathrm{hr}$ before being exposed to four of the highest concentrations of the nanomaterials used in our previous study $\left(5 \mu \mathrm{g} / \mathrm{cm}^{2}\right.$ to $\left.80 \mu \mathrm{g} / \mathrm{cm}^{2}\right)$.

We found that pre-treatment with Trolox prevented the cytotoxicity induced by five of the ten nanomaterials investigated (NM 110 (ZnO uncoated), NM 111 ( $\mathrm{ZnO}$ coated), NM $300(\mathrm{Ag})$, NRCWE $001\left(\mathrm{TiO}_{2}\right.$ rutile $\left.10 \mathrm{~nm}\right)$ and NRCWE 004 $\left(\mathrm{TiO}_{2}\right.$ rutile $\left.94 \mathrm{~nm}\right)$ ) (Figure 4c, e, g, $\mathrm{m}$ and $\mathrm{s}$ ). We also observed that Trolox reduced IL8 secretion for all NMs with the exception of Ag, wherere IL8 secretion appeared increased, but these changes were not significant (Figure 4h).

\section{DNA damage in C3A cells}

In order to investigate the possible DNA damage caused by the panel of nanomaterials, C3A cells were exposed to the NMs for $4 \mathrm{hr}$. In this study we chose the $\mathrm{LC}_{20}$ value for each individual $\mathrm{NM}$ plus one concentration above $\left(2 x \mathrm{LC}_{20}\right)$ and one below $\left(0.5 \mathrm{x} \mathrm{LC}_{20}\right)$ (The $\mathrm{LC}_{50}$ and $\mathrm{LC}_{20}$ values have been previously described) [17].

We observed that DNA damage was most evident following exposure to NM $101\left(\mathrm{TiO}_{2}-7 \mathrm{~nm}\right)$ and NRCWE $002\left(\mathrm{TiO}_{2}-10 \mathrm{~nm}\right.$ positively charged) (Figure $\left.5 \mathrm{a}, \mathrm{h}\right)$. We also noted a small but significant increase in percentage tail DNA following exposure to seven of the other eight NMs investigated (NRCWE 003 - negatively charged $\mathrm{TiO}_{2} 10 \mathrm{~nm}$ being the exception) (Figure 5).

Long-term 8 week NM 300 (Ag) exposed cells had a small but significant increase in tail moment compared to our cell only control, however there was no significant difference between short and long term exposure to $\mathrm{LC}_{20}$ of $\mathrm{Ag}$ (data not shown).

Addition of the FPG enzyme to the samples resulted in increased percentage of tail DNA following treatment with the NMs. This indicates that the damage witnessed is partially due to oxidative DNA damage.

\section{Discussion}

This study was conducted as part of a large consortium (FP7 project - ENPRA) to investigate the potential hazard of a wide range of nanomaterials on a variety of targets in order to use the data for generation of a structure activity relationship and for modelling risk assessment. For this reason, the wide dose response ranges were used in order to allow calculation of values such as $\mathrm{LC}_{50}$ for comparisons between different materials and cell target types both in vitro and in vivo. Our previous studies have demonstrated that the panel of nanomaterials investigated could be divided into a high toxicity group (two $\mathrm{ZnO}$ and one $\mathrm{Ag}$ ) and a low toxicity group (five $\mathrm{TiO}_{2}$ and two MWCNTs) according to their ability 


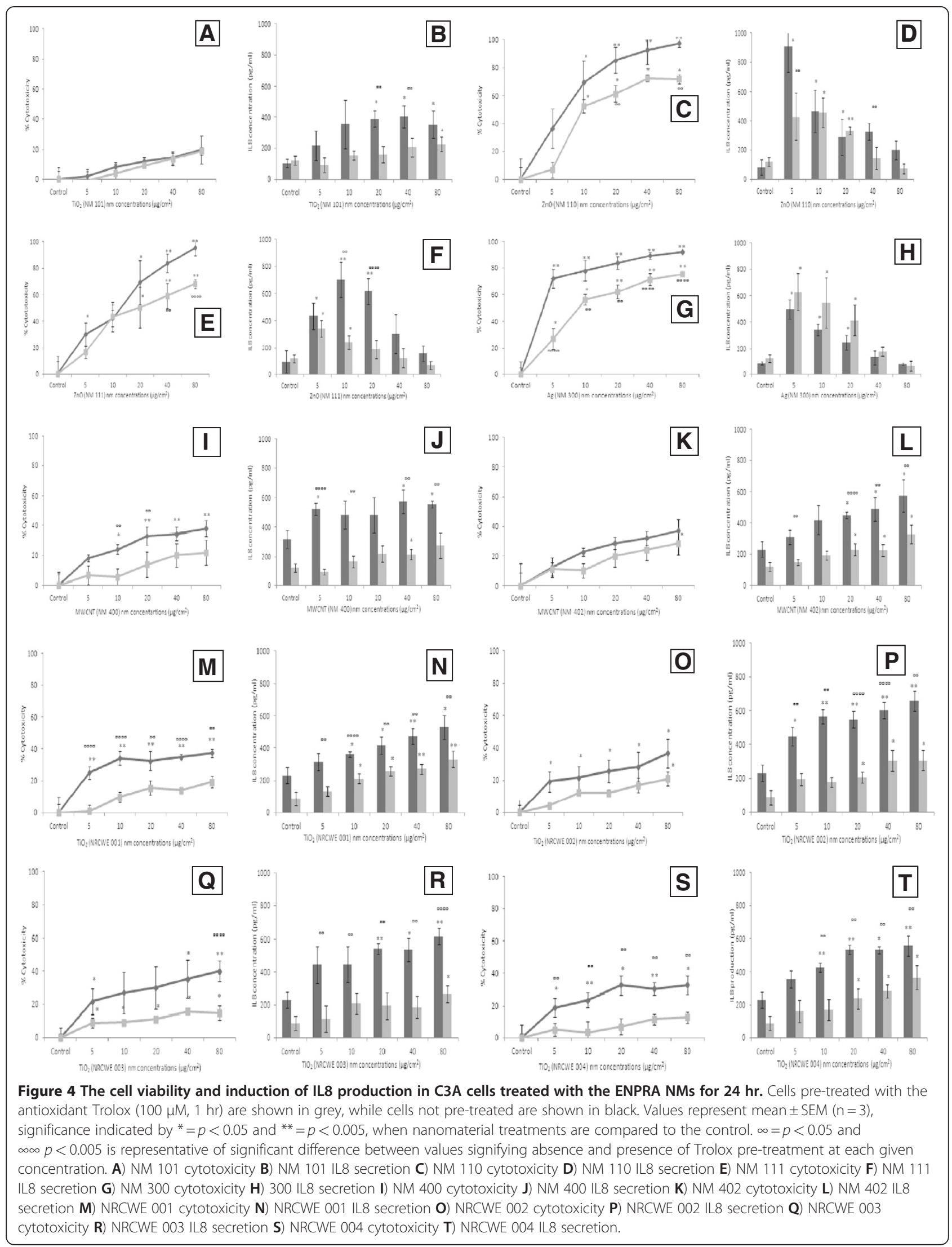




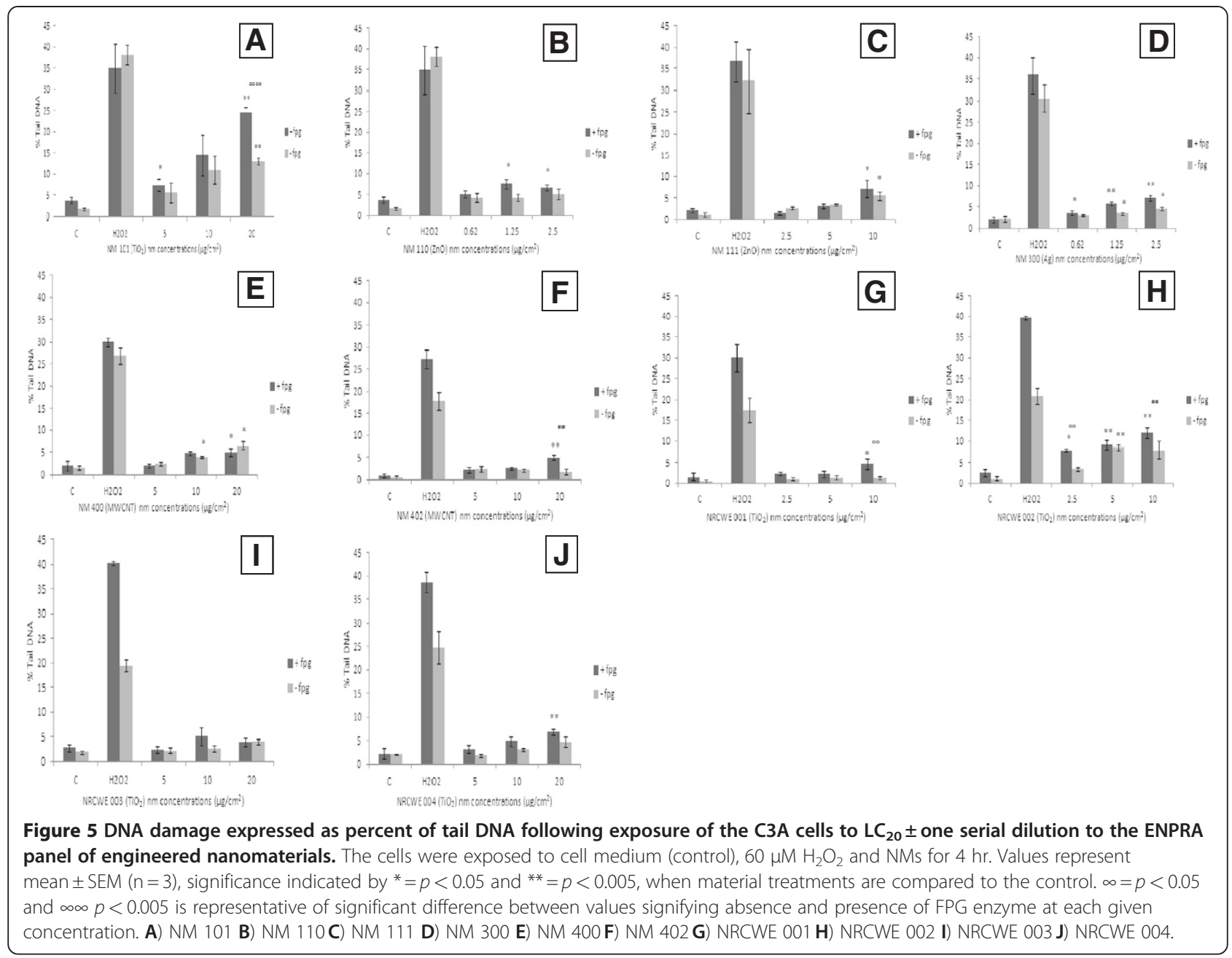

to induce cytotoxicity in the C3A cell line [17] primary human hepatocytes [Kermanizadeh, et al., 2012 - Nanotoxicology in press] and primary rat hepatocytes [Filippi, et al., manuscript in preparation]. The discussion below is therefore structured to allow comparison between the low toxicity and high toxicity materials in order to ascertain whether this pattern is retained across a wider array of sub-lethal endpoints.

Investigated nanomaterials were characterized by a combination of analytical techniques in order to infer

Table 2 Summary of the observed effects on C3A hepatocytes following exposure to the ENPRA panel of nanomaterials

\begin{tabular}{lllll}
\hline NM & LC50 (WST-1) & GSH Depletion & Increase in intracellular ROS levels & DNA damage \\
\hline NM $\mathbf{1 0 1}$ & $>80 \mu \mathrm{g} / \mathrm{cm}^{2}$ & No & Large & Yes \\
NM $\mathbf{1 1 0}$ & $5-10 \mu \mathrm{g} / \mathrm{cm}^{2}$ & Yes & None & Yes \\
NM $\mathbf{1 1 1}$ & $10-20 \mu \mathrm{g} / \mathrm{cm}^{2}$ & Yes & Small & Yes \\
NM $\mathbf{3 0 0}$ & $1.25-2.5 \mu \mathrm{g} / \mathrm{cm}^{2}$ & Yes & None & Yes \\
NM $\mathbf{4 0 0}$ & $>80 \mu \mathrm{g} / \mathrm{cm}^{2}$ & Yes & Large & Yes \\
NM $\mathbf{4 0 2}$ & $>80 \mu \mathrm{g} / \mathrm{cm}^{2}$ & No & Large & Yes \\
NRCWE 001 & $>80 \mu \mathrm{g} / \mathrm{cm}^{2}$ & No & Large & Yes \\
NRCWE 002 & $>80 \mu \mathrm{g} / \mathrm{cm}^{2}$ & No & Large & Yes \\
NRCWE 003 & $>80 \mu \mathrm{g} / \mathrm{cm}^{2}$ & No & Large & No \\
NRCWE $0 \mathbf{0 0 4}$ & $>80 \mu \mathrm{g} / \mathrm{cm}^{2}$ & & Large & Yes \\
\hline
\end{tabular}


primary physical and chemical properties useful to understand their toxicological behaviour (Table 1) [17]. In order to investigate how the panels of nanomaterials behaved in complete MEM, the hydrodynamic size distributions of the NMs was measured by DLS after the nanomaterials were dispersed in the complete medium between 1-128 $\mathrm{gg} / \mathrm{ml}$ [17]. Furthermore the $24 \mathrm{hr}$ dissolution of $\mathrm{ZnO}$ (NM 110 and $\mathrm{NM} \mathrm{111)} \mathrm{and} \mathrm{the} \mathrm{Ag}$ NMs (NM 300) was investigated in the complete C3A medium using atomic absorption spectroscopy. We found that the two $\mathrm{ZnO} \mathrm{NMs}$ were highly soluble in the medium while the amount of dissolved Ag was very low [17].

Both of the materials with significant solubility are in the high toxicity group while the low solubility nanomaterials are in the low toxicity group. This could lead to the conclusion that increased solubility leads to higher toxicity. However, this is too general as a conclusion, as real toxicity is dependent on the chemical element in question (Table 2).

Initially we tested the ability of the chosen NMs to induce glutathione depletion in C3A cells. Exposure to the $\mathrm{Ag}$ and the two $\mathrm{ZnO}$ NMs resulted in significant GSH depletion following a $24 \mathrm{hr}$ exposure. For these highly toxic NMs glutathione depletion at the higher concentrations might be associated with cell death rather than a specific oxidative stress response. In contrast, MWCNTs were also able to significantly deplete glutathione at doses which did not influence cell viability, suggesting that MWCNTs induced oxidative stress in these cells. The $\mathrm{TiO}_{2}$ materials had no significant effect on the glutathione content of the cells suggesting that they are unable to induce oxidative stress in liver cells in dark experimental conditions.

Next, we investigated intracellular ROS levels following exposure of the ENPRA panel of NMs. Interestingly the $\mathrm{Ag}$ and uncoated $\mathrm{ZnO}$ NMs did not generate detectable intracellular ROS according to the DCFH-DA assay at $24 \mathrm{hr}$, although small yet significant levels could be detected for coated $\mathrm{ZnO}$ (NM 111). This assay is dependent on intact viable cells therefore exposure to highly toxic nanomaterials could result in lower levels of fluorescence from the DCFH-DA assay. Furthermore, investigations into earlier exposure time-points $(6 \mathrm{hr})$ revealed higher levels of DCF fluorescence for all of the NMs tested. We therefore suggest that the DCFH assay is not suitable for investigating the cellular ROS response to highly toxic NMs, or that it should be limited to relatively low concentrations and early time points for such materials.

In contrast we were able to observe a concentration dependant increase in ROS levels following exposure to the low toxicity nanomaterials (five $\mathrm{TiO}_{2}$ and two MWCNT NMs) indicating firstly that these low toxicity materials are able to generate intracellular ROS and secondly that the assay is suitable for these lower toxicity NMs. It is interesting to note that the ROS production by MWCNT translated into a GSH depletion at $24 \mathrm{hr}$, but the same was not true for the $\mathrm{TiO}_{2} \mathrm{NMs}$. Either the cells were sufficiently protected with antioxidant defence mechanisms to prevent GSH depletion by the $\mathrm{TiO}_{2} \mathrm{NM}$, or a longer time point might be required to assess such an effect. Another explanation for the ROS generation by the MWCNT might be that the iron residues within the nanotubes may contribute to the oxygen species generation (e.g. via $\mathrm{Fe}^{2+}$ fenton reaction).

A recent study investigated a rat derived liver cell line (BRL 3A) and $10 \mathrm{~nm} \mathrm{Ag} \mathrm{NMs} \mathrm{(up} \mathrm{to} 50 \mu \mathrm{g} / \mathrm{ml}-24 \mathrm{hr}$ exposure) and reported a significant GSH depletion [23]. In a contradictory study however the effects of silver NPs $(220 \mu \mathrm{g} / \mathrm{ml})$ on primary mice hepatocytes in vitro revealed a small increase in intracellular GSH levels subsequent to a $24 \mathrm{hr}$ exposure to the particles [24]. Studies in which human Chang liver cells were exposed to Ag NPs also induced intracellular ROS generation [25] which was contrary to findings in this study. However it is important to note that these finding were after much shorter exposure times [25] which could therefore mean that viability of these cells was sufficient to allow ROS to be detected. Exposure of HepG2 cell to a $100 \mathrm{~nm} \mathrm{ZnO}$ NMs resulted in high toxicity associated with reactive oxygen species and oxidative stress [26].

We could not identify any studies in which the impacts of MWCNTs on hepatocytes was reported, but intraperitoneal injection of functionalized SWCNTs into Swiss-Webster mice resulted in increased ROS levels within liver cells and enhanced the activities of serum amino-transferases [27].

In a recent set of trials the use of nanoparticulate $\mathrm{TiO}_{2}$ (intragastric administration) resulted in mice liver damage with the authors suggesting oxidative stress as the mechanism of cytotoxicity [28]. In another study exposure of mice (intragastric administration) to $\mathrm{TiO}_{2} \mathrm{NMs}$ for 60 days resulted in hepatocyte apoptosis associated by increased reactive oxygen species accumulation and decreased stress-related gene expression levels of superoxide dismutase and glutathione peroxidise [29]. These studies add support to our observations for MWCNT and $\mathrm{TiO}_{2}$ with respect to ROS production in liver cells.

The lipophilic antioxidant Trolox decreased the Ag and $\mathrm{ZnO}$ induced cytotoxicity as well as the $\mathrm{ZnO}$ induced IL8 production. With respect to Ag, Trolox appeared to enhance IL8 production although this was not statistically significant. This might seem counterintuitive, as it could be interpreted as protection of the cells from particle-induced cytotoxicity by the antioxidant, thereby enhancing their ability to induce a proinflammatory response at doses that were toxic in 
previous experiments without the addition of Trolox [17]. The pre-treatment of the C3A cells with Trolox prevented the low toxicity nanomaterials from increasing DCF fluorescence, confirming that the DCFH assay was measuring oxidative activity. The pre-treatment with Trolox also resulted in protection against cytotoxicity following exposure to relatively high concentrations of $\mathrm{TiO}_{2}$ NMs (NRCWE 001, NRCWE 004). In addition, Trolox pre-treatment decreased the IL8 secretion following exposure to these NMs. Taken together these results suggest that ROS play a key role in the upregulation of cytokines in hepatocytes following exposure to $\mathrm{ZnO}, \mathrm{TiO}_{2}$ and the MWCNT NMs.

To our knowledge there have been no nanotoxicological studies that have pre-treated liver cells with Trolox in vitro, however Trolox pre-treatment of human macrophages significantly reduced the toxicity of superparamagnetic iron oxide [30] and $\mathrm{TiO}_{2} \mathrm{NMs}$ [31]. The authors of two other studies in which human monocytes were pre-treated with Trolox before exposure to fine carbon black also noted a decrease in the pro inflammatory cytokine TNF- $\alpha[14,32]$. Contrary to these findings, pre-treatment with Trolox of J774.A1 macrophages [33], PC 12 cells (cell line derived from a pheochromocytoma of the rat adrenal medulla) [34], N9 (murine microglial cell line) [34] followed by exposure to quantum dots did not prevent toxicity or cytokine production by the cells.

We also investigated any possible genotoxic effects following exposure to the NMs at sub-lethal concentrations. Short term exposure $(4 \mathrm{hr})$ of C3A cells to the ENPRA panel of nanomaterials resulted in a small but significant increase in percent tail DNA for nine of the ten NMs investigated (the negatively charged $\mathrm{TiO}_{2}$ NRCWE 003 being the exception). Exposure of the C3A cells to $\mathrm{LC}_{20}$ of $\mathrm{Ag} \mathrm{NM}$ for 8 weeks resulted in a marginal yet significant increase in tail moment compared to the control, however there was no significant difference between short and long term exposure to this particular particle. We also noted a small but significant increase in DNA damage following exposure to both $\mathrm{ZnO}$ and the two MWCNT NMs. Genotoxicity was most evident following exposure to NM $101\left(\mathrm{TiO}_{2}\right.$ $7 \mathrm{~nm}$ ) and NRCWE 002 (positively charged $\mathrm{TiO}_{2}$ $10 \mathrm{~nm}$ ). The relative genotoxicity of the particle panel is therefore strikingly different to their ranking with respect to cytotoxicity. This therefore indicates the importance of assessing sub-lethal effects and the need for further chronic in vivo studies to assess the validity of these short term in vitro observations.

It is important to emphasis the role of FPG enzyme in the comet assay. The enzyme measures specific oxidative DNA mediated strand breaks so it is not surprising to see increased tail length in the presence of the enzyme following exposure to one of the MWCNTs (NM 402) and three of the $\mathrm{TiO}_{2}$ NMs (NM 101, NRCWE 001 and NRCWE 002). As seen from the data in the DCFH-DA assay there was significant increase in intracellular ROS following exposure of the hepatocytes to these materials. Therefore these findings suggest that ROS plays an important role in the genotoxicity witnessed for the MWCNTs and $\mathrm{TiO}_{2} \mathrm{NM}$ investigated in this study.

In a recent study exposure of human epidermal cell line A431 to $\mathrm{TiO}_{2}$ resulted in significant oxidative stress related DNA damage [35]. Our short-term exposure findings are similar in part to a study in which low concentration exposures of $90 \mathrm{~nm} \mathrm{TiO}{ }_{2} \mathrm{NMs}$ to human embryo hepatocytes did not induce DNA breaks or chromosome damage [36]. Another study using A549 cells alveolar epithelial cells, HepG2 hepatocytes and NRK-52E kidney cells were exposed to a panel of NMs including $\mathrm{TiO}_{2}, \mathrm{Al}_{2} \mathrm{O}_{3}$, gold and MWCNTs discovered that genotoxicity was weak and that DNA damage was limited to single-strand beaks and/or alkali-labile sites [37].

In conclusion, utilizing this particular in vitro hepatocyte model showed that the NM which induced a low cytotoxicity $\left(\mathrm{TiO}_{2}\right.$ and MWCNTs) in our previous study [17] generated intracellular ROS, induced oxidative stress (GSH depletion), and that an oxidative mechanism was involved in both the induction of IL8 protein production and genotoxicity according to the Comet assay. The highly toxic Ag and ZnO NMs appeared to work by different mechanisms. Silver did not generate ROS measurable by the DCFH-DA assay, although pretreatment with an antioxidant may marginally enhance IL8 production by the hepatocytes suggesting that the toxic mechanisms might be partially mediated by ROS. In addition the data indicates that Ag particles are capable of enhancing a pro-inflammatory response, providing that they are not too toxic. A good understanding of the dissolution kinetics of the nanomaterials during the preparation steps and in the cell mediums are crucial in evaluating of the toxicology of these materials. In a previous publication [17] we have shown that less than $1 \%$ of Ag (NM 300) dissolves in this medium after $24 \mathrm{hr}$ of incubation, so it is very unlikely that the damage to the cells is due totally to the release of $\mathrm{Ag}$ ions. The $\mathrm{ZnO}$ NMs were highly soluble in the C3A medium so there is a real possibility that the high toxicity of these particles is in part due to the release of ions.

Future studies will concentrate on co-culture of primary rat liver cells with phagocytic cells (hepatocytes and Kupffer cells) with particular attention on cytotoxicity and cytokine production as well as trying to ascertaining the potential mechanism driving inflammation in particular the role of reactive oxygen. Studies conducted by project partners will employ other target cells such as macrophages, lung epithelial cells, fibroblasts, endothelial 
cells and renal proximal tubule epithelial cells. In vivo studies are also being conducted for comparison with in vitro models. All of this data will be combined into a database to be used for a structure activity relationship and for risk assessment modelling.

\section{Competing interests}

The authors declare that they are no competing interests.

\section{Authors' contributions}

AK has carried out the experiments within this study. BKG, GRH and VS have all been heavily involved in the preparation and revision of the manuscript. All authors have read and approved the final manuscript.

\section{Funding}

This work has been financially supported by the European seventh framework programme co-operation [Grant code - NMP4-SL-2009-228789].

\section{Acknowledgements}

The authors are grateful to colleagues at Heriot-Watt University and Edinburgh Napier University in particular Dr David Brown and Dr Julia Varet.

\section{Author details}

'Heriot-Watt University, School of Life Sciences, Nanosafety Research Group Edinburgh EH14 4AS, UK. ${ }^{2}$ Edinburgh Napier University, School of Life, Sport and Social Sciences, Sighthill Campus, Sighthill Court, Edinburgh EH11 4BN, UK.

Received: 13 January 2012 Accepted: 5 July 2012

Published: 19 July 2012

\section{References}

1. Woodrow W. (http://www.nanotechproject.org/inventories/consumer/ browse/products/) Accessed 9-5-2011.

2. Hoet PHM, Hohlfeld IB, Salata O: Nanoparticles - known and unknown health risks. Journal of Nanobiotechnology 2004, 2:12-27.

3. Papp T, Schiffmann D, Weiss D, Castronova V, Vallyathan V, Rahman Q: Human health implications of nonmaterial exposure. Nanotoxicology 2008, 2:9-27.

4. Nel A, Xia T, Madler L, Li N: Toxic potential of materials at the nanolevel. Science 2006, 311:622-627.

5. Diesen DL, Kuo PC: Nitric Oxide and redox regulation in the liver: Part I. General considerations and redox Biology in Hepatitis. Journal of Surgical Research 2009, 162:95-109.

6. Sadauskas E, Jacobson NR, Danscher G, Soltenberg M, Larsen A, Kreyling W, Wallin H: Bio-disruption of gold nanoparticles in mouse lung following intratracheal instillation. Chemistry Central Journal 2009, 3:16-23.

7. Kmiec Z: Cooperation of liver cells in health and disease. Advances in Anatomy, Embryology and Cell Biology 2001, 161:1-151.

8. Semmler-Behnke M, Wolfgang KG, Lipka J, Fertsch S, Wenk A, Takeneka S, Schmid G, Brandau W: Bio-distribution of 1.4 and $18 \mathrm{~nm}$ gold particles in rats. Small 2008, 12:2108-2111

9. Geiser M, Kreyling WG: Deposition and biokenetics of inhaled nanoparticles. Particle and Fibre Toxicology 2010, 7:2-19.

10. Lipka J, Semmler-Behnke M, Sperling RA, Wenk A, Takenaka S, Schleh C, Kissel T, Parak WJ, Wolfgang KG: Biodistribution of PEG-modified gold nanoparticles following intratracheal instillation and intravenous injection. Biomaterials 2010, 31:6574-6581.

11. Kang KJ: Mechanism of hepatic ischemia/reperfusion injury and protection against reperfusion injury. Transplantation Proceedings 2002, 34:2659-2661.

12. Glantzounis GK, Salacinski HJ, Yang W, Davidson BR, Seifalian AM: The contemporary role of anti-oxidant therapy in attenuating liver ischemia reperfusion injury: a review. Liver Transplantation 2005, 11:1031-1047.

13. Martindale JL, Holbrook NJ: Cellular response to oxidative stress: Signalling for suicide and survival. Journal of Cellular Physiology 2002, 192:1-15

14. Brown DM, Donaldson K, Brom PJ, Schins P, Dehnhardt M, Gilmour P, Jiminez LA, Stone V: Calcium and ROS mediated activation of transcription factors and TNF-a cytokine gene expression in macrophages exposed to ultrafine particles. American Journal of Lung Physiology 2004, 286:344-353.

15. Friedberg EC: Out of the shadows and into the light: emergence of DNA repair. Trends in Biochemical Sciences 1995, 20:381.

16. Abraham RT: Cell cycle checkpoint signalling through the ATM and ATR kinases. Genes and Development 2001, 15:2177-2196.

17. Kermanizadeh A, Pojana $G$, Gaiser BK, Birkedal R, Bilaničová D, Wallin $H$ Jensen KA, Sellergren B, Hutchison GR, Marcomini A, Stone V: In vitro assessment of engineered nanomaterials using C3A cells: Cytotoxicity, pro-inflammatory cytokines and function markers. Nanotoxicology 2012, ahead of print.

18. Jacobsen NR, Pojano G, Wallin $H$, Jensen KA: Nanomaterial dispersion protocol for toxicological studies in ENPRA. Internal ENPRA Project Report. The National Research Centre for the Working Environment 2010, available on request from the NRCWE.

19. Senft AP, Dalton TP, Shertzer HG: Determining Glutathione and Glutathione Disulfide using the fluorescence probe $o$-Phthalaldehyde. Analytical Biochemistry 2000, 280:80-86.

20. Speit G, Schutz P. Hoffmann H: Sensitivity of FPG protein towards alkylation damage in the comet assay. Toxicology Letters 2004, 146:151-158.

21. Wilklund SJ, Agurelli E: Aspects of design and statistical analysis in the Comet assay. Mutagenesis 2003, 18:167-175.

22. Kain J, Karlsson HL, Moller L: DNA damage induced by micro- and nanoparticles - interaction with FPG influences the DNA oxidation in the comet assay. Mutagenesis 2012, 27:491-500.

23. Hussain SM, Hess KL, Gearhart JM, Geiss KT, Schlager JJ: In vitro toxicity of nanoparticles in BRL 3A rat liver cells. Toxicology In vitro 2005, 19:975-983.

24. Arora S, Jain J, Rajwade JM, Paknikar KM: Interactions of silver nanoparticles with primary mouse fibroblasts and liver cells. Toxicology and Applied Pharmacology 2009, 236:310-318.

25. Piao MJ, Kang KA, Lee IK, Kim HS, Kim S, Choi JY, Choi J, Hyun JW: Silver nanoparticles induce oxidative cell damage in human liver cells through inhibition of reduced glutathione and induction of mitochondrial involved apoptosis. Toxicology Letters 2011, 201:92-100.

26. Akhtar MJ, Ahamed A, Kumar S, Khan MAM, Ahmad J, Alrokayan SA: Zin oxide nanoparticles selectively induce apoptosis in human cancer cells through reactive oxygen species. International Journal of Nanomedicine. 2012, 7:845-857.

27. Patlolla A, McGinnis B, Tchounwou P: Biochemical and histopathological evaluation of functionalized single-walled carbon nanotubes in SwissWebster mice. Journal of Applied Toxicology 2011, 2011(31):75-83.

28. Wang J, Li N, Zheng L, Wang SS, Wang Y, Zhao XY, Duan YM, Cui YL, Zhou M, Cai JW, Gong SJ, Wang H, Hong FS: P38-Nrf-2 signalling pathway of oxidative stress in mice caused by nanoparticulate $\mathrm{TiO}_{2}$. Biological Trace Element Research 2011, 140:186-197.

29. Cui Y, Gong X, Duan Y, Li N, Hu R, Liu H, Hong M, Zhou M, Wang L, Wang $\mathrm{H}$, Hong F: Hepatocyte apoptosis and its molecular mechanisms in mice caused by titanium dioxide nanoparticles. Journal of Hazardous Materials 2010, 183:874-880

30. Lunov O, Syrovets T, Buchele B, Jiang XE, Rocker C, Tron K, Nienhaus GU, Walther $P$, Mailander $V$, Landfester $K$, Simmet T: The effects of carboxydextran-coated supermagnetic iron oxide nanoparticles on c-Jun $\mathrm{N}$-terminal kinase-mediated apoptosis in human macrophages. Biomaterials 2010, 2010(31):5063-5071.

31. Miller TJ, Knapton A, Adeyemo O, Noory LS, Weaver JL, Hanig JP, Honchel R, Zhang J, Espandiari P, Benedick MF, Umbreit TH, Tomazic-Jezic VJ, Sadrieh $\mathrm{N}$ : Toxicology of Titanium dioxide $\left(\mathrm{TiO}_{2}\right)$ nanoparticles: in vitro and in vivo evaluation of macrophage uptake of $\mathrm{TiO}_{2}$. The Journal of the Federation of American Societies for Experimental Biology 2007, 6:812-814.

32. Brown DM, Hutchison L, Donaldson K, Stone V: The effects of $\mathrm{PM}_{10}$ particles and oxidative stress on macrophages and lung epithelial cells: modulating the effects of calcium signalling antagonists. American Journal of Lung Physiology 2007, 292:1444-1451.

33. Clift MJ, Boyles MS, Brown DM, Stone V: An investigation into the potential for different surface coated quantum dots to cause oxidative stress and affect macrophage cell signalling in vitro. Nanotoxicology 2010, 4:139-149.

34. Lovric J, Bassan HS, Cuie Y, Fortin GRA, Winnik FM, Maysinger D: Differences in sub-cellular distribution and toxicity of green and red emitting $\mathrm{CdTe}$ quantum dots. Journal of Molecular Medicine 2005, 83:377-385. 
35. Shukla RK, Sharma V, Pandey AK, Singh S, Sultana S, Dhawan A: ROSmediated genotoxicity induced by titanium dioxide nanoparticles in human epidermal cells. Toxicology In Vitro 2011, 25:231-241.

36. Shi Y, Zhang JH, Jiang M, Zhu LH, Tan HQ, Lu B: Synergistic genotoxicity caused by low concentration of Titanium dioxide nanoparticles and p - DDT in human hepatocytes. Environmental and Molecular Mutagenesis 2010, 51:192-204.

37. Simon A, Gouget B, Mayne M, Herlin N, Reynaud C, Degrouard J, Carriere M: In vitro investigation of $\mathrm{TiO}_{2}, \mathrm{Al2O}$, Au nanoparticles and multi-walled carbon nanotubes cyto- and genotoxicity on lung, kidney cells and hepatocytes. Toxicology Letters 2007, 172:36.

doi:10.1186/1743-8977-9-28

Cite this article as: Kermanizadeh et al:: An in vitro liver model assessing oxidative stress and genotoxicity following exposure of hepatocytes to a panel of engineered nanomaterials. Particle and Fibre Toxicology 2012 9:28.

\section{Submit your next manuscript to BioMed Central and take full advantage of:}

- Convenient online submission

- Thorough peer review

- No space constraints or color figure charges

- Immediate publication on acceptance

- Inclusion in PubMed, CAS, Scopus and Google Scholar

- Research which is freely available for redistribution 